\section{BSDHT PRESIDENT DEMONSTRATES GOOD ORAL HYGIENE}

On 3 February the President of the British Society of Dental Hygiene and Therapy (BSDHT), Michaela ONeill, visited children at St Joseph's Primary School in County Antrim to teach them how to look after their oral health.

The pupils took part in brushing demonstrations and fun activities and were all given guidance and tuition on how to brush their teeth correctly. They were also given toothbrushes, toothpaste and a reward chart to take home with them which were donated by Procter \& Gamble (Oral B).

Michaela ONeill said: 'Having the chance to teach young children about the importance of their oral health and show them about basic oral hygiene is an excellent opportunity to give them the skills they need to take care of their teeth throughout the rest of their life.

'According to findings from the last survey of Children's Dental Health, children in Northern Ireland have been shown to have some of the poorest levels of oral health compared to other regions of the United Kingdom. It is stating the obvious but something needs to be done about these figures, and the British Society of Dental Hygiene and Therapy will be doing all they can to tackle this ultimately preventable problem.'

The BSDHT hopes to raise awareness of how to prevent tooth decay and members will be volunteering their time to help teach correct methods of oral hygiene to children as part of the Early Years curriculum.

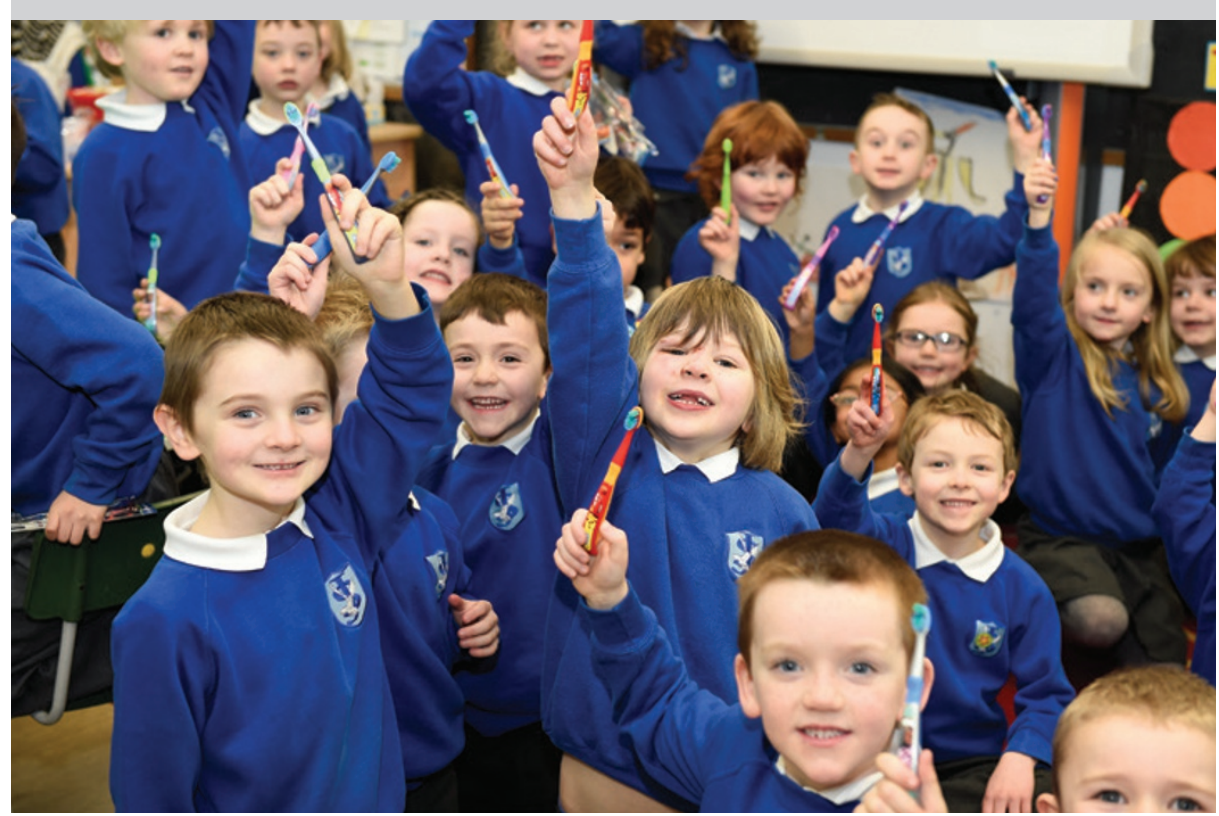

\begin{tabular}{|c|c|}
\hline \multicolumn{2}{|c|}{ CHILDREN'S FOOD HEROES AND ZEROES OF 2014} \\
\hline Table 1 Children's food heroes & zeroes of 2014 \\
\hline Heroes & Zeroes \\
\hline $\begin{array}{l}\text { School Food Plan and the } \\
\text { Department of Education - revised } \\
\text { school food standards, cooking skills } \\
\text { and food education are back on the } \\
\text { curriculum and universal infant free } \\
\text { school meals have been introduced } \\
\text { British Dietetic Association's Dietitians } \\
\text { in Obesity Management Specialist } \\
\text { Group - removal of sweets/chocolates } \\
\text { from tills } \\
\text { British Heart Foundation - petition to } \\
\text { introduce } 9 \text { pm watershed for junk } \\
\text { food adverts on TV and tightening } \\
\text { regulations around online marketing. }\end{array}$ & $\begin{array}{l}\text { Committee of Advertising Practice and the Advertising } \\
\text { Standards Authority - progress to better protect children } \\
\text { from junk food marketing has been slow } \\
\text { Coca-Cola - for introducing Coca-Cola Life, a product } \\
\text { that contains over four teaspoons of sugar per } 300 \\
\text { ml can } \\
\text { The Department of Health's Responsibility Deal - for } \\
\text { failing to pledge on food promotion } \\
\text { Party Health Spokespeople - with only months until } \\
\text { the General Election, the Children's Food Campaign } \\
\text { remains unconvinced that any of the parties are } \\
\text { going to be offering the bold policies needed to } \\
\text { tackle obesity. }\end{array}$ \\
\hline
\end{tabular}

\section{STANDARDISED CIGARETTE PACKAGING TO BE FAST-TRACKED}

The Government is to fast-track legislation to introduce 'plain' packaging for cigarettes by 2016. After a series of public consultations on the issue, MPs will be asked to vote on the plan before the General Election.

The Stirling Review published in April 2014 - an independent review of public health evidence for standardised tobacco packaging - found that standardised packaging is less appealing than branded packaging; that graphic and text health warnings are more credible and memorable on standardised packaging; and that products in standardised packages are more likely to be perceived as harmful than those in branded packaging with colours and descriptors.

\section{CARING FOR DENTAL PATIENTS WITH EATING DISORDERS}

CPD answers - January 2015 issue (http:// www.nature.com/articles/bdjteam20159)

1D. all of the above

2A. palatal aspects of the maxillary anterior teeth

3B. knuckles of the dominant hand $4 \mathrm{D}$. all of the above

Do you have a news story that you would like included in BDJ Team? Send your press release or a summary of your story to the Editor at bdjteam@nature.com. 